\title{
Factors Affecting Customers' Decision for Taking out Bank Loans: A Case of Greek Customers
}

\author{
Christos C. Frangos ${ }^{1}$, Konstantinos C. Fragkos ${ }^{2}$, loannis Sotiropoulos ${ }^{3}$, \\ Giannis Manolopoulos ${ }^{4}$ and Aikaterini C. Valvi ${ }^{5}$ \\ ${ }^{1}$ Department of Business Administration, Technological Educational Institute (TEI) of Athens, Greece \\ ${ }^{2}$ Division of Medicine, University College London, UK \\ ${ }^{3}$ Department of Finance and Auditing, Technological Educational Institute (TEI) of Epirus, \\ Preveza, Greece \\ ${ }^{4}$ Technological Educational Institute (TEI) of Thessaloniki, Greece \\ ${ }^{5}$ Department of Management, Birkbeck, University of London, UK
}

\begin{abstract}
The concept of loyalty has received much consideration from both academics and practitioners in various industries and is a predominant research topic in the banking industry. Identifying the factors that affect customers' decision to take out a loan from a particular bank has become an essential asset for many banks in their effort to attract new customers and to maintain existing ones. The purpose of the present study is to identify factors that influence Greek customers' decision to take out a loan from commercial banks. A number of variables (demographics, service quality and satisfaction) have been examined as potential factors influencing customers' decision to take out a loan. A randomly selected sample of Greek citizens $(\mathrm{n}=277)$ was chosen in order to test our hypotheses. A questionnaire with self-determined scales was created after ensuring the instrument's validity through confirmatory factor analysis. Logistic regression results show that personal marital status, customer service, shop design and interest rates are the most significant predictors of taking loans. Several managerial implications suggest bank managers should focus on giving loans to single individuals as well as change their interest rates policies by decreasing rates for all kinds of loans, especially housing loans.
\end{abstract}

Keywords: customer satisfaction, service quality, bank loans, logistic regression

\section{Introduction}

The recent global financial crisis has highlighted the intense competition between banks for attracting customers; thus, research on selection criteria used by customers to choose a bank for doing business has been enriched with new methodologies, findings and recommendations for both banks and customers. This is ever more important when we take into account that banks and generally the financial system have lost their reputation and credibility, as a result of certain financial transactions which brought about the economic crisis (e.g. subprime lending in the USA; Lehmann Brothers collapse).

Hence, the banking industry appears as one of the most rapidly emerging sectors needing to identify the main factors that

Copyright (C) 2012 Christos C. Frangos, Konstantinos C. Fragkos, Ioannis Sotiropoulos, Giannis Manolopoulos and Aikaterini C. Valvi.This is an open access article distributed under the Creative Commons Attribution License unported 3.0, which permits unrestricted use, distribution, and reproduction in any medium, provided that original work is properly cited. Contact Author: Christos C. Frangos E-mail: cfragos@teiath.gr 
lead to maintenance of existing customers and ways to attract new ones. According to Karatepea et al. (2005) and Sharma and Rao (2010), total customer satisfaction is accurately achieved when bank managers search and identify exactly what customers want. The issue of "how customers select banks" has been addressed broadly in the literature by researchers and practitioners (Anderson et al., 1976; Evans, 1979; Kaynack and Yavas 1985). Particularly, the current literature has given much consideration and attention to investigate bank selection criteria from different segments (Yue and Tom, 1995). Customer demographic characteristics, and mainly age group, are one of the most significant factors, which have been investigated by several studies (Almossawi, 2001). The objective of the present paper is to identify factors for bank loans demand in a Greek population sample. The researchers aim to formulate a model which will help banking policies determine effectively future marketing strategies.

The Banking System and Loans in Greece

Banks in Greece have historically played a dominant role in channelling financial savings from surplus to deficit economic units, whereas the relative importance of other financial institutions, such as mutual funds and insurance companies, in financial intermediation was until recently very limited, but is currently increasing. The special role of banks in financial intermediation was further enhanced by the following features of the financial system (Brissimis et al., 2001). First, Greek banks were prohibited from engaging directly in financial service activities other than their traditional loan and deposit functions. The Greek banking system was subject to strict regulatory requirements, including restrictions on freely determined interest rates, the financing of various sectors of the economy and activities in the foreign exchange market. In the late 1980s, a gradual relaxation of the regulatory environment in Greece took place due to the increasing interdependence of EU economies, increasing pressure for the opening of markets and anticipation of EMU. Administratively determined interest rates by the Central Bank of Greece were finally abolished and Greek banks became free to negotiate interest rates with customers based on market conditions (Alexiou and Sofoklis, 2009). These significant changes, together with technological advances, contributed to a rapid expansion of the banking system, which is now characterized by a high degree of concentration and competitiveness. In 2006, there were 46 domestic and foreign banks and other credit institutions operating in Greece.

Domestic banks can be grouped into two main categories: universal banks (commercial and investment banks) and specialized credit institutions. A higher banking concentration ratio than in the rest of the Eurozone makes Greece a de facto oligopoly, allowing the maintenance of high loan-deposit interest spreads (Athanasoglou et al., 2005) (see Table 1).

Table 1. Greek Banking Sector Concentration and Market Shares of Main Competitors

\begin{tabular}{|c|c|c|c|c|c|c|c|}
\hline \multicolumn{2}{|c|}{ Banks } & Assets & $\begin{array}{c}\text { Market } \\
\text { Share }\end{array}$ & Loans & $\begin{array}{c}\text { Market } \\
\text { Share }\end{array}$ & Deposits & $\begin{array}{c}\text { Market } \\
\text { Share }\end{array}$ \\
\hline $\mathbf{1}$ & $\begin{array}{c}\text { National Bank of } \\
\text { Greece }\end{array}$ & 61.3 & $22.7 \%$ & 32.7 & $19.9 \%$ & 44.5 & $25.3 \%$ \\
\hline $\mathbf{2}$ & Eurobank & 50.1 & $18.6 \%$ & 30.1 & $18.3 \%$ & 30.3 & $17.2 \%$ \\
\hline $\mathbf{3}$ & Alpha Bank & 46.7 & $17.3 \%$ & 28.2 & $17.2 \%$ & 20.3 & $11.6 \%$ \\
\hline $\mathbf{4}$ & Piraeus Bank & 27.9 & $10.4 \%$ & 18.7 & $11.4 \%$ & 14.6 & $8.3 \%$ \\
\hline $\mathbf{5}$ & Emporiki Bank & 21.8 & $8.1 \%$ & 16.1 & $9.8 \%$ & 16.3 & $9.3 \%$ \\
\hline $\mathbf{6}$ & ATEBank & 20.5 & $7.6 \%$ & 13.6 & $8.3 \%$ & 18.1 & $10.3 \%$ \\
\hline & Total & 228.3 & $84.7 \%$ & 139.4 & $84.9 \%$ & 144.1 & $82.0 \%$ \\
\hline
\end{tabular}

Amounts in $€$ millions; Source: Alexiou and Sofoklis (2009) 
Clearly, six banks control more than $80 \%$ of the market, as measured in terms of assets, loans or deposits. As a result of consolidation in the industry, Greek banks now enjoy economies of scale and scope, which is reflected in their high profitability with returns on equity exceeding $20 \%$ in 2006 (Alexiou and Sofoklis, 2009).

\section{Literature Review}

Many studies, mainly from the USA and some European countries, have tried to identify the most important determinants of customers' behaviour when selecting banking products such as loans (Parasuraman et al., 1991a, 1991b; Parasuraman et al., 1988; Goode and Moutinho, 1995; Newman and Cowling, 1996; Kennington et. al., 1996; Drake et. al., 1998; Lee and Marlowe, 2003; Oldfield and Baron, 2000; Zineldin, 1996; Sekaran, 1992; Nunnally, 1978). A considerable number of studies on criteria for selecting banking products have been carried out in developing countries and small islands in the Mediterranean Sea as well (Denton and Chan, 1991; Thwaites and Vere, 1995; Yavas et al., 1997; Ta and Har, 2000; Sureshchandar et al., 2003; Salime, 2010). Increasing levels of competition for financial services have increased the banks' need to find and attract new market segments. In this context, university students have become a target group of potential bank customers both as a source of new accounts and future profitability. Several surveys among university students have been designed to answer the question: Why do students select a particular bank to open a new account and to do business with from a large number of alternatives? The answer to such a question should bankers develop specific marketing strategies for attracting new customers and retaining existing ones.

According to Boyd et al. (1994), the main factors that determine young (under 21 years old) customer bank selection in a sample of the head of the household were: a) bank's reputation; b) location; c) hours of operation; d) interest of saving accounts; and e) the provision of convenient. Less important factors were the friendliness of bank employees and the modern nature of their facilities.

Many studies from the USA found that the main factors affecting customers' bank selection were a) distance from home or work (Kaufman, 1967; Riggall, 1980); b) bank service quality, including hours of operation, queuing size and fund safety (Laroche et al., 1986; Javalgi et al., 1989); and c) friendliness of a bank's personnel and influence from customers' relatives (Mason and Mayer, 1974; Kazeh and Decker, 1993).

Kennington et al. (1996) compared their findings with studies conducted in other countries in order to determine whether bankers need to follow new policies for attracting customers, in the relatively new freemarket economy of Poland. They concluded that the most important selection factors for bank choice by Polish customers were: reputation, price (reduced interest rate on loans and high interest rate on savings) and services offered. In this respect, Polish bank customers do not differ from customers of the banking industry in other countries.

It is worth noticing the study by Javalgi et al. (1989) in the USA, which found that financial factors (interest for saving accounts, fund safety and loan availability) play an important role in customers' decision to take out a loan from a particular bank. Moreover, other studies like the study executed by Erol et al. (1990) on customers of conventional and Islamic banks in Jordan, found that another important factor affecting customers' decision to choose a bank is bank confidentiality. This finding was supported also by Haron et al. (1994) and Holstius and Kaynak (1995). The former surveyed 301 Muslim and non-Muslim commercial bank customers in Malaysia to determine selection a dual banking environment. Their main findings apart from banks' confidentiality were: fast and efficient services, speed of transactions and friendliness of bank staff. The latter investigated the importance of selected patronage factors used by Finnish customers by collecting data from 258 bank customers in Finland. The results showed once again that customer service, service quality, bank's personnel openness and confidentiality were the key driving factors affecting customer decision to select a bank.

Furthermore, customers from both domestic and foreign banks in Hong Kong were investigated by Kaynak and Kucukemiroglu (1992) in order to recognize factors affecting their decision to select a bank. Results showed once more that suitable location, parking close to a bank and the existence of a wide range of loans and mortgages were the main reasons. In addition, studies conducted on university students have shown similar results. For instance, Kazeh and Decker (1993) asked 209 university students in Maryland, USA their opinion about factors influencing customers' decision to choose a bank 
with the main findings being not surprisingly different from the aforementioned. Specifically, students reported that service charges, reputation, interest charged on loans, quick loan approval and friendly bank staff were the major reasons.

Additionally, other potential factors that affect customers' selection choice of a bank are services' efficiency, bank reputation, bank fees, convenient location and interest rates on saving accounts and loans (Yue and Tom, 1995). It is worth mentioning the study conducted by Mylonakis et al. (1998) investigating 811 bank customers in Greece (in the greater Athens area) asking them to identify the important bank selection criteria that urban consumers of saving accounts use in the Hellenic bank market. The interesting finding was that Greek customers decide similarly to bank customers in advanced bank markets, who are seeking good service in safe, fast and technologically modern environments. The most influential factors reported by Greek customers were location convenience and quality of service (attention to customers, personalized service, no queues).

The importance of technology is prominent in the banking industry and affects strongly customers' decision whether to choose a particular bank. Coyle (1999) confirmed the importance of technology and speed: with the participation of 250 bank vendors, he observed the "Future Bank" trade show in Minneapolis (USA). This study showed that the competitive bank of the future is the one which can offer speedy, technology based services (e.g. ATM) backed by effective staff training. Moreover, Almossawi (2001) and Lenka et al. (2009) support the importance of technology in commercial bank selection. Managers should realise that young people enjoy dealing with advanced technical devices such as ATMs. This indicates that, in their bank selection, the new generation of customers tends to put more emphasis on the factors which give them quick and convenient access to bank services, rather than factors related to hospitality, bank premises conditions and bank location. In Singapore, Huu and Kar (2000) found that students place high emphasis on pricing (suitable interest rates and reduced service charges) and product dimensions, like speedy service and availability of ATMs near the college.

Cicic et al. (2004) and Maddern et al. (2007) point out that banks' personnel incompetence and lack of courtesy are major reasons customers leave their banks. Their studies reveal that customers regard highly knowledgeable and competent personnel coupled with friendly and courteous.

According to Mokhlis (2009), recommendations from acquaintances are also among important factors in selecting a bank for both male and female customers. Almossawi (2001) found that recommendations from friends and relatives are of relevance despite the fact that young people prefer acting independently. In contrast, Gerrard and Cunningham (2001) found that third party influences are of little importance in commercial bank selection by customers. A study conducted by Chua (1981) on bank selection criteria found that social factors such as family and friends recommendations have an important influence on decisions by Asian customers for choosing a bank to trust their money. Al-Ajmi et al. (2009) compared the motives of bank customers for conventional and Islamic banks. They found that Islamic religious belief, social responsibility and pricing are the most important factors in choosing a bank to do business with.

According to Kamakodi and Khan (2008), Indian banking industry is undergoing metamorphosis in terms of adoption of technology and automation. New generation of private sector banks which came into existence in the last ten years have gained a substantial market share and government owned banks are losing market share to these new banks. It is very important for banks to understand the preferences of the customers to offer the services required both to attract new clients and protect the existing client-base from migrating to other banks. A survey was conducted and results obtained from 292 clients were analysed to understand the factors that influence bank selection reasons. The top 10 parameters based on importance were found to be Safety of Funds, secured ATMs, ATMs availability, reputation, personal attention, pleasing manners, confidentiality, closeness to work, timely service and friendly staff willing to work.

Among the most important selection criteria in bank selection is service quality (Laroche et al., 1986; Sinkula and Lawtor, 1988; Ying and Chua, 1989; Newman, 2001). In service quality studies, measurement of service quality is carried out within the banking establishments. A four-factor, seventeen -item scale for measuring service quality was devised by Avkiran (1994) and it has been used in branches of an Australian commercial bank. Angur et. al. (1999) examined 
alternative measures of service quality in Indian banks, using four-dimensional measures. They found that service performance had higher discriminant validity than the service quality scale. In China's banking industry, Zhou (2004) used a three-factor instrument for measuring bank service quality. Arasli et. al. (2005) compared service quality perceptions of both Greek and Turkish bank customers in the Turkish part of North Cyprus and found that the service quality scale had a four-dimensional structure and bank customers of both Greek and Turkish origin were influenced by the "assurance" factor in their satisfaction from bank service. Parasuraman et. al. (1988) developed a service quality scale which has been used by Senyucel (2009) in the Turkish part of North Cyprus to compare the attitudes towards bank selection by Turkish Cypriots and Greek Cypriots bank customers. He found that the most important selection factor for Turkish Cypriots customers was "assurance", whereas for Greek Cypriots customers it was "responsiveness".

Finally, Bejou et al. (1998) researched the role of trust, ethics and knowledge that would supplement sales personnel in developing customer satisfaction in the area of financial services. Bloemer et al. (1998) studied the relationship between image, service quality, satisfaction and loyalty towards banks. The study claims that reliability and position in market are important drivers of retail bank loyalty.

After reviewing the literature, it is possible to draw three conclusions: (a) Bank selection criteria vary across countries and cultures; (b) in order of importance, bank selection criteria are: pricing, service quality, friendly and efficient staff and convenience of bank and ATM location; and (c) there is a bright future for internet banking provided that the criteria of trust, security and reliability are satisfied.

\section{Research Hypotheses}

Until now, there hasn't been a study exploring the factors Greek citizens choose banks to take loans from. Based on the literature review presented above, the researchers consider the following hypotheses:

H1: Demographic Factors (age, gender, personal marital status, salary, salary band) affect the decision to take a loan.

H2: Service Quality (Shop Design, customer Services) affects the decision to take a loan.

H3: The banks loans policy affects the decision to take a loan (e.g. general loan conditions, interest rates, insurance/guarantee policies and instalments policy).

H4: Satisfaction from the bank's services increases the probability of taking a loan from that bank.

\section{Methodology}

\section{Instrument Development}

A survey was conducted to test the hypotheses. An instrument to measure the variables was developed by adopting and adapting scales wherever possible. Minor revisions were made where possible. Additional questions were inserted in order to reflect particularities of the Greek financial conditions. Items were either 4point Likert answers (1=Not at all, $4=$ Very much) or Yes/No answers. All items can be provided by the authors upon request.

\section{Data Collection and General Characteristics}

The survey was carried out in Athens, Greece from February to April 2011 through selfadministered questionnaires. All in all, 277 questionnaires were completed. A demographic summary is shown in Table 2. 
Table 2. Demographic Characteristics of the Sample

\begin{tabular}{|c|c|c|}
\hline & Frequency & Percentage \\
\hline \multicolumn{3}{|l|}{ Gender } \\
\hline Male & 122 & 44.0 \\
\hline Female & 151 & 54.5 \\
\hline N/A & 4 & 1.4 \\
\hline \multicolumn{3}{|l|}{ Age } \\
\hline $20-30$ & 95 & 34.3 \\
\hline $30-40$ & 64 & 23.1 \\
\hline 40-50 & 70 & 25.3 \\
\hline $50-60$ & 30 & 10.8 \\
\hline 60-70 & 4 & 1.4 \\
\hline N/A & 14 & 5.1 \\
\hline \multicolumn{3}{|l|}{ Education level } \\
\hline Primary education & 36 & 13.0 \\
\hline Secondary education & 70 & 25.3 \\
\hline University education & 122 & 44.0 \\
\hline Postgraduate degrees & 49 & 17.7 \\
\hline \multicolumn{3}{|l|}{ Employment Status } \\
\hline Employee & 225 & 81.2 \\
\hline Unemployed & 34 & 12.3 \\
\hline $\begin{array}{l}\text { Not working for personal } \\
\text { reasons }\end{array}$ & 17 & 6.1 \\
\hline N/A & 1 & .4 \\
\hline \multicolumn{3}{|l|}{ Sector of employment } \\
\hline Public sector & 136 & 49.1 \\
\hline Private sector & 109 & 39.4 \\
\hline Self-employed & 32 & 11.6 \\
\hline \multicolumn{3}{|l|}{$\begin{array}{l}\text { Gross Monthly Wages of } \\
\text { last/current job }\end{array}$} \\
\hline$\leq 1000 €$ & 148 & 53.4 \\
\hline $1001-2000 €$ & 54 & 19.5 \\
\hline $2001-3000 €$ & 40 & 14.4 \\
\hline $3001-4000 €$ & 18 & 6.5 \\
\hline Over $4000 €$ & 17 & 6.1 \\
\hline \multicolumn{3}{|l|}{ Income group belonging to: } \\
\hline$\leq 8000 €$ & 113 & 40.8 \\
\hline $8001-15000 €$ & 72 & 26.0 \\
\hline $15001-25000 €$ & 47 & 17.0 \\
\hline $25001-35000 €$ & 25 & 9.0 \\
\hline Over $35000 €$ & 20 & 7.2 \\
\hline \multicolumn{3}{|l|}{$\begin{array}{l}\text { Personal Property Bracket } \\
\text { belonging to: }\end{array}$} \\
\hline$\leq 10000 €$ & 134 & 48.4 \\
\hline $10001-50000 €$ & 76 & 27.4 \\
\hline $50001-100000 €$ & 28 & 10.1 \\
\hline $100001-200000 €$ & 17 & 6.1 \\
\hline Over $200000 €$ & 22 & 7.9 \\
\hline
\end{tabular}

N/A: Not answered

\section{Data Analysis}

Data Analysis was conducted with PASW 18.0 and Amos 18.0. First the researchers performed a confirmatory factor analysis of the questionnaire's underlying structure.
Additionally, t-tests and chi-square tests were performed to examine univariate differences andassociations and then a binary logistic regression in order to determine the predictive factors of taking bank loans. 


\section{Results}

\section{Instrument Validity}

At first, the researchers performed a confirmatory factor analysis of the instrument's latent structure. Several items were dropped from the original questionnaire that shared high degree of residual variance with other items, according to recommended methodology guidelines (Segars, 1997).

After these items were dropped, the CFA reached a satisfactory model fit: the normalized $\chi^{2}$ was the following: $1.85\left(\chi^{2}=1804.602, \mathrm{df}=\right.$ 972), the RMSEA was 0.056 (below 0.08) and the CFI was 0.804 . Moreover, Factor Loadings are in their great majority were over 0.5 . All these measures are indicative of an acceptable fit of our questionnaire. The CFA path diagram is shown in Figure 1 and factor loadings are shown in Table 3. Convergent validity was assessed through reliability assessment (composite reliability and Cronbach's alpha) which are all above the accepted values of 0.7 and the correlations between the factors are mostly under the square root of the AVE (Table 4).

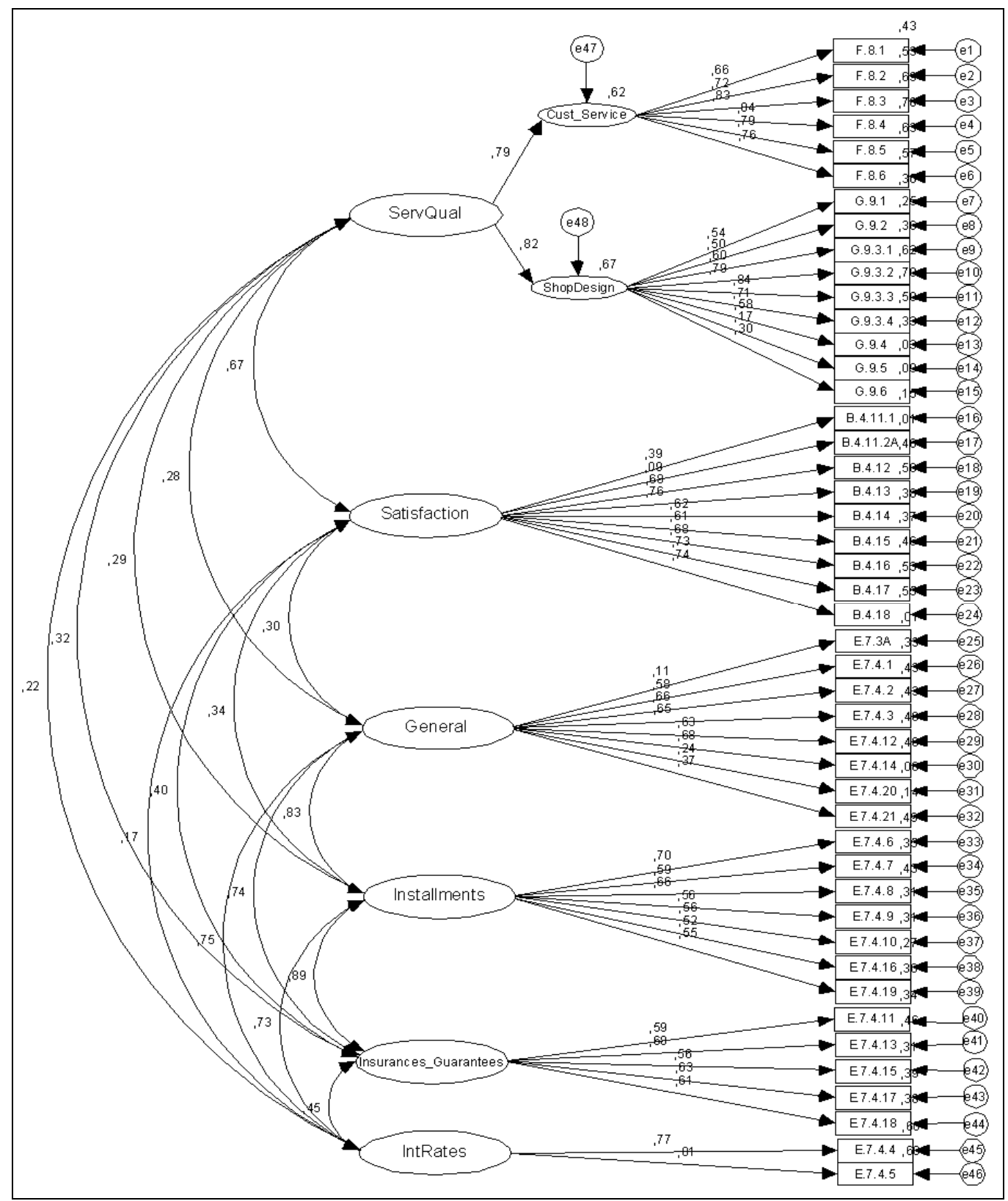

Fig 1. Confirmatory Factor Analysis Model 
Table 3. Factor Loadings from CFA and Scale Reliability

\begin{tabular}{|c|c|c|c|c|c|}
\hline Items & Questions & $\begin{array}{l}\text { Factor } \\
\text { Loading }\end{array}$ & AVE & CR & Cronbach's alpha \\
\hline \multicolumn{6}{|c|}{ First Order Variables } \\
\hline \multicolumn{6}{|c|}{\begin{tabular}{l|l} 
Service & \\
Quality & \\
\end{tabular}} \\
\hline \multicolumn{6}{|c|}{ Customer Service } \\
\hline F.8.1 & Staff confidentiality and trust & 0.655 & 0.59 & 0.914 & 0.895 \\
\hline F.8.2 & Polite staff & 0.725 & & & \\
\hline F.8.3 & Knowledge and skills of staff & 0.833 & & & \\
\hline F.8.4 & professionalism and credibility of staff & 0.84 & & & \\
\hline F.8.5 & $\begin{array}{l}\text { searching for the best possible solutions to the } \\
\text { financial problem }\end{array}$ & 0.791 & & & \\
\hline F.8.6 & $\begin{array}{l}\text { Are potential customer complaints managed } \\
\text { effectively by the bank's staff? }\end{array}$ & 0.758 & & & \\
\hline \multicolumn{6}{|l|}{ Shop Design } \\
\hline G.9.1 & spread of the branch network & 0.544 & 0.35 & 0.800 & 0.771 \\
\hline G.9.2 & $\begin{array}{l}\text { Are the ATMs of the bank which you cooperate with } \\
\text { sufficient in number? }\end{array}$ & 0.495 & & & \\
\hline G.9.3.1 & Satisfaction of time waiting for service & 0.602 & & & \\
\hline G.9.3.2 & Speed of service from the cashiers & 0.787 & & & \\
\hline G.9.3.3 & Sufficient number of cashiers & 0.839 & & & \\
\hline G.9.3.4 & Sufficient number of bank personnel & 0.707 & & & \\
\hline G.9.4 & $\begin{array}{l}\text { Satisfaction with the layout, atmosphere and } \\
\text { cleanliness }\end{array}$ & 0.575 & & & \\
\hline G.9.5 & Layout, decoration and the modern equipment & 0.175 & & & \\
\hline G.9.6 & Bank reputation & 0.299 & & & \\
\hline \multicolumn{6}{|l|}{ Satisfaction } \\
\hline B.4.11.1 & $\begin{array}{l}\text { Do you think that it is important for you to know } \\
\text { them }\end{array}$ & 0.393 & 0.39 & 0.847 & 0.821 \\
\hline B.4.11.2A & $\begin{array}{l}\text { Is it annoying for you to be preoccupied with such } \\
\text { information (the new products)? }\end{array}$ & 0.088 & & & \\
\hline B.4.12 & $\begin{array}{l}\text { How likely do you consider the event that in the } \\
\text { future you will be a customer of the same bank? }\end{array}$ & 0.68 & & & \\
\hline B.4.13 & $\begin{array}{l}\text { Are you satisfied with the variety of products- } \\
\text { services provided by the bank you cooperate with? }\end{array}$ & 0.764 & & & \\
\hline B.4.14 & $\begin{array}{l}\text { Do you have enough information about your bank } \\
\text { accounts? }\end{array}$ & 0,62 & & & \\
\hline B.4.15 & Do you have enough information about your loan? & 0.61 & & & \\
\hline B.4.16 & $\begin{array}{l}\text { Do you have sufficient information for the other } \\
\text { products (e.g. cheques) which are issued by the bank } \\
\text { you cooperate with? }\end{array}$ & 0.68 & & & \\
\hline B.4.17 & $\begin{array}{l}\text { Does the bank you cooperate with take care of } \\
\text { immediate and effective solution of any problem you } \\
\text { might have? }\end{array}$ & 0.727 & & & \\
\hline B.4.18 & $\begin{array}{l}\text { Are you satisfied with the quality of the services that } \\
\text { the bank offers you? }\end{array}$ & 0.743 & & & \\
\hline \multicolumn{6}{|l|}{ Loan Factors } \\
\hline \multicolumn{6}{|l|}{ General } \\
\hline E.7.3A & Your tendency for making risky decisions is high & 0.11 & 0.28 & 0.757 & 0.679 \\
\hline E.7.4.1 & $\begin{array}{l}\text { Important reason for loan: speed of approval and } \\
\text { immediate payout }\end{array}$ & 0.575 & & & \\
\hline E.7.4.2 & Important reason for loan: Flexibility in execution & 0.655 & & & \\
\hline E.7.4.3 & Important reason for loan: Simpler procedures & 0.654 & & & \\
\hline E.7.4.12 & Important reason for loan : Reduced costs of loan & 0.632 & & & \\
\hline E.7.4.14 & $\begin{array}{l}\text { Important reason for loan : Less bureaucratic } \\
\text { formalities }\end{array}$ & 0.68 & & & \\
\hline E.7.4.20 & Important reason for loan :Influence of others & 0.238 & & & \\
\hline
\end{tabular}




\begin{tabular}{|c|c|c|c|c|c|}
\hline E.7.4.21 & $\begin{array}{l}\text { Important reason for loan : Financial performance of } \\
\text { the bank }\end{array}$ & 0.371 & & & \\
\hline \multicolumn{6}{|l|}{ Instalments } \\
\hline E.7.4.6 & $\begin{array}{l}\text { Important reason for loan: Ability to finance up to } \\
100 \% \text { of property value (in housing) }\end{array}$ & 0.699 & 0.35 & 0.819 & 0.780 \\
\hline E.7.4.7 & $\begin{array}{l}\text { Important reason for loan: Low instalments over a } \\
\text { long period }\end{array}$ & 0.595 & & & \\
\hline E.7.4.8 & $\begin{array}{l}\text { Important reason for loan :Ability to design the } \\
\text { amount and frequency of instalments based on your } \\
\text { own capabilities }\end{array}$ & 0.657 & & & \\
\hline E.7.4.9 & $\begin{array}{l}\text { Important reason for loan: Deferral of instalments if } \\
\text { you have something unexpected }\end{array}$ & 0.559 & & & \\
\hline E.7.4.10 & $\begin{array}{l}\text { Important reason for loan :Choice of borrowing in } \\
\text { Euros or other currency }\end{array}$ & 0.557 & & & \\
\hline E.7.4.16 & $\begin{array}{l}\text { Important reason for loan :Possibility of partial or } \\
\text { total early repayment anytime you want }\end{array}$ & 0.515 & & & \\
\hline E.7.4.19 & Important reason for loan :Long repayment period & 0.552 & & & \\
\hline \multicolumn{6}{|c|}{ Insurances/Guarantees } \\
\hline E.7.4.11 & $\begin{array}{l}\text { Important reason for loan : No need of underwriting } \\
\text { property (housing) }\end{array}$ & 0.586 & 0.38 & 0.755 & 0.756 \\
\hline E.7.4.13 & $\begin{array}{l}\text { Important reason for loan :No large premium of life- } \\
\text { earthquake }\end{array}$ & 0.68 & & & \\
\hline E.7.4.15 & $\begin{array}{l}\text { Important reason for loan: The existence of one or } \\
\text { more guarantors }\end{array}$ & 0.559 & & & \\
\hline E.7.4.17 & $\begin{array}{l}\text { Important reason for loan: Ability to provide an } \\
\text { insurance program to protect the payment of } \\
\text { instalments }\end{array}$ & 0.627 & & & \\
\hline E.7.4.18 & $\begin{array}{l}\text { Important reason for loan :Life insurance of the } \\
\text { borrower }\end{array}$ & 0.614 & & & \\
\hline \multicolumn{6}{|l|}{ Interest Rates } \\
\hline E.7.4.4 & Important reason for loan, Competitive interest rates & 0.773 & 0.63 & 0.850 & 0.771 \\
\hline E.7.4.5 & $\begin{array}{l}\text { Important reason for loan :privileged terms in } \\
\text { comparison with the other banks }\end{array}$ & 0.811 & & & \\
\hline \multicolumn{6}{|c|}{ Second Order Variables } \\
\hline $\begin{array}{l}\text { Service } \\
\text { Quality }\end{array}$ & & & 0.64 & 0.929 & 0.883 \\
\hline \multicolumn{2}{|c|}{ Customer Service } & 0.785 & & & \\
\hline \multicolumn{2}{|c|}{ Shop Design } & 0.816 & & & \\
\hline
\end{tabular}

CR: composite Reliability, AVE: Average Variance Extracted

Table 4. Discriminant Validity Assessed through Correlations between the Factors. Diagonal Represents the Square Root of AVE

\begin{tabular}{|l|c|c|c|c|c|c|c|c|}
\hline & Satisfaction & $\begin{array}{c}\text { Interest } \\
\text { Rates }\end{array}$ & $\begin{array}{c}\text { Insurances } \\
\text { Guarantees }\end{array}$ & Instalments & General & $\begin{array}{c}\text { Service } \\
\text { Quality }\end{array}$ & $\begin{array}{c}\text { Shop } \\
\text { Design }\end{array}$ & $\begin{array}{c}\text { Customer } \\
\text { Service }\end{array}$ \\
\hline Satisfaction & 0.624 & & & & & & & \\
\hline Interest Rates & 0.171 & 0.792 & & & & & & \\
\hline Insurances/Guarantees & 0.403 & 0.446 & 0.615 & & & & & \\
\hline Instalments & 0.343 & 0.734 & 0.891 & 0.594 & & & & \\
\hline General & 0.299 & 0.746 & 0.745 & 0.831 & 0.531 & & & \\
\hline Service Quality & 0.672 & 0.215 & 0.321 & 0.294 & 0.277 & 0.801 & & \\
\hline Shop Design & 0.548 & 0.176 & 0.262 & 0.24 & 0.226 & 0.816 & 0.594 & \\
\hline Customer Service & 0.528 & 0.169 & 0.252 & 0.231 & 0.218 & 0.785 & 0.641 & 0.77 \\
\hline
\end{tabular}

AVE: Average Variance Extracted 


\section{Univariate Analyses}

The researchers examined the mean difference between people taking loans and those not. All differences are insignificant except for the mean difference of attitudes towards interest rates, where people not taking a loan have significantly lower attitudes for interest rates than people taking a loan (Table 5). The researchers also examined the associations of taking a loan with certain demographic variables (Table
6). The factors which have a significant association with taking loans are gender, personal marital status, the employment sector $(\mathrm{p}<0.05)$ and borderline the annual income group customers belong to $(p=0.083)$. Particularly, women are 1.71 times more likely to take a loan than a man [Odds Ratio (OR) = 1.71 (95\% CI 1.04-2.80)] and married people are less likely to take a loan than single individuals [OR (married to unmarried $)=0.46(95 \%$ CI 0.28-0.76)] .

Table 5. Mean Differences and T-Test for People not Taking a loan Minus People Taking a Loan

\begin{tabular}{|l|c|c|c|}
\hline Factors & Mean Difference \pm S.E. & p-value & t-value (df) \\
\hline Service Quality & & & \\
\hline Customer Service & $-0.92 \pm 0.57$ & 0.111 & $-1.599(248)$ \\
\hline Shop Design & $1.07 \pm 0.72$ & 0.139 & $1.483(249)$ \\
\hline Satisfaction & $0.46 \pm 0.75$ & 0.540 & $0.614(241)$ \\
\hline Products & $0.04 \pm 0.33$ & 0.905 & $0.119(241)$ \\
\hline Loan-associated factors & & & \\
\hline General & $0.05 \pm 0.57$ & 0.934 & $0.083(250)$ \\
\hline Instalments & $-0.24 \pm 0.58$ & 0.680 & $-0.413(250)$ \\
\hline Insurance/Guarantees & $0.43 \pm 0.48$ & 0.364 & $0.909(247)$ \\
\hline Interest Rates & $-0.52 \pm 0.19$ & 0.007 & $-2.729(194)$ \\
\hline
\end{tabular}


Table 6. Associations of Taking loans with Demographic Factors

\begin{tabular}{|c|c|c|c|c|}
\hline & & \multicolumn{2}{|c|}{ Have you ever received a loan? } & \multirow[t]{2}{*}{ Total } \\
\hline & & No & Yes & \\
\hline \multirow{2}{*}{$\begin{array}{l}\text { Gender } \\
\chi^{2}=4.566, d f=1, p=0.033 \\
\text { OR }(\text { female to male })=1.71 \\
(95 \% \text { CI } 1.04-2.80)\end{array}$} & Male & $55(52.9)$ & $67(39.6)$ & $122(44.7)$ \\
\hline & Female & $49(47.1)$ & $102(60.4)$ & $\begin{array}{c}151 \\
(55.3)\end{array}$ \\
\hline \multirow{5}{*}{$\begin{array}{l}\text { Age } \\
\chi^{2}=6.911, d f=4, p=0.141\end{array}$} & $20-30$ & 32 (31.1) & $63(39.4)$ & $95(36.1)$ \\
\hline & $30-40$ & $31(30.1)$ & $33(20.6)$ & $64(24.3)$ \\
\hline & $40-50$ & $30(29.1)$ & $40(25.0)$ & $70(26.6)$ \\
\hline & $50-60$ & $10(9.7)$ & $20(12.5)$ & $30(11.4)$ \\
\hline & Over 60 & $0(0.0)$ & $4(2.5)$ & $4(1.5)$ \\
\hline \multirow{2}{*}{$\begin{array}{l}\text { Personal marital status } \\
\chi^{2}=9.299, d f=1, p=0.002 \\
\text { OR }(\text { married to unmarried })=0.46 \\
(95 \% \text { CI } 0.28-0.76)\end{array}$} & Not married & $39(37.9)$ & $93(57.1)$ & $\begin{array}{c}132 \\
(49.6)\end{array}$ \\
\hline & Married & $64(62.1)$ & $70(42.9)$ & $\begin{array}{c}134 \\
(50.4)\end{array}$ \\
\hline \multirow{4}{*}{$\begin{array}{l}\text { Education level } \\
\chi^{2}=1.696, \mathrm{df}=3, \mathrm{p}=0.638\end{array}$} & Primary education & $10(9.6)$ & $26(15.0)$ & $36(13.0)$ \\
\hline & Secondary education & $27(26.0)$ & $43(24.9)$ & $70(25.3)$ \\
\hline & University education & $48(46.2)$ & $74(42.8)$ & $\begin{array}{c}122 \\
(44.0)\end{array}$ \\
\hline & Postgraduate degrees & $19(18.3)$ & $30(17.3)$ & $49(17.7)$ \\
\hline \multirow[t]{3}{*}{$\begin{array}{l}\text { Employment Status } \\
\chi^{2}=1.095, d f=2, p=0.578\end{array}$} & Employed & $86(83.5)$ & $139(80.3)$ & $\begin{array}{c}225 \\
(81.5) \\
\end{array}$ \\
\hline & Unemployed & $10(9.7)$ & $24(13.9)$ & $34(12.3)$ \\
\hline & $\begin{array}{l}\text { Not working for } \\
\text { personal reasons }\end{array}$ & $7(6.8)$ & $10(5.8)$ & $17(6.2)$ \\
\hline \multirow[t]{3}{*}{$\begin{array}{l}\text { Sector of employment } \\
\chi^{2}=11.118, d f=2, p=0.004\end{array}$} & Public sector & $42(40.4)$ & $94(54.3)$ & $\begin{array}{c}136 \\
(49.1)\end{array}$ \\
\hline & Private sector & $42(40.4)$ & 67 (38.7) & $\begin{array}{c}109 \\
(39.4)\end{array}$ \\
\hline & Self-employed & $20(19.2)$ & $12(6.9)$ & $32(11.6)$ \\
\hline \multirow{5}{*}{$\begin{array}{l}\text { Gross Monthly Income of } \\
\text { previous/current job } \\
\chi^{2}=7.362, d f=4, p=0.118\end{array}$} & $\leq 1000 €$ & $47(45.2)$ & $101(58.4)$ & $\begin{array}{c}148 \\
(53.4)\end{array}$ \\
\hline & $1001-2000 €$ & $23(22.1)$ & $31(17.9)$ & $54(19.5)$ \\
\hline & $2001-3000 €$ & $21(20.2)$ & $19(11.0)$ & $40(14.4)$ \\
\hline & $3001-4000 €$ & $8(7.7)$ & $10(5.8)$ & $18(6.5)$ \\
\hline & Over $4000 €$ & $5(4.8)$ & $12(6.9)$ & $17(6.1)$ \\
\hline \multirow[t]{5}{*}{$\begin{array}{l}\text { Annual Income group } \\
\chi^{2}=9.742, d f=5, p=0.083\end{array}$} & $\leq 8000 €$ & $39(36.5$ & $74(42.8)$ & $\begin{array}{c}113 \\
(40.8)\end{array}$ \\
\hline & $8001-15000 \mathrm{E} €$ & $23(22.1)$ & $49(28.3)$ & $72(26.0)$ \\
\hline & $15001-25000 €$ & $22(21.2)$ & $25(14.5)$ & $47(17.0)$ \\
\hline & $25001-35000 €$ & $12(11.5)$ & $13(7.5)$ & $25(9.0)$ \\
\hline & Over $35000 €$ & $8(7.7)$ & $12(6.9)$ & $20(7.2)$ \\
\hline \multirow{5}{*}{$\begin{array}{l}\text { Personal Property Band } \\
\text { belonging to } \\
\chi^{2}=6.429, d f=4, p=0.169\end{array}$} & $\leq 10000 €$ & $46(44.2)$ & 88 (50.9) & $\begin{array}{c}134 \\
(48.4)\end{array}$ \\
\hline & $10001-50000 €$ & $32(30.8)$ & $44(25.4)$ & $76(27.4)$ \\
\hline & $50001-100000 €$ & $15(14.4)$ & $13(7.5)$ & $28(10.1)$ \\
\hline & $100001-200000 €$ & $6(5.8)$ & $11(6.4)$ & $17(6.1)$ \\
\hline & Over $200000 €$ & $5(4.8)$ & $17(9.8)$ & $22(7.9)$ \\
\hline
\end{tabular}




\section{Logistic Regression}

Direct logistic regression was performed to assess the impact of a number of factors on the likelihood that respondents would report having taken a loan. The model contained 11 independent variables [personal marital status, sector of employment, personal property bracket, products produced, Service Quality (Customer Service, Shop Design), Satisfaction, Loans-associated factors (General, Instalments, Insurance/Guarantees, Interest Rates)]. The dependent variable was the question whether customers received a loan $(\mathrm{No}=0$, Yes =1). The full model containing all predictors is statistically significant, $\chi^{2}=$ $36.371, p=0.002$, indicating that the model was able to distinguish between respondents who took and didn't take a loan. The model as a whole explained between 14.6\% (Cox and Snell R-Square) and $19.5 \%$ (Nagelkerke R-Squared) of the variance in loan-taking and correctly classified $67.1 \%$ of cases.

As shown in Table 7, only four of the independent variables made a unique statistically significant contribution to the model [Personal Marital Status, Customer service, Shop Design (number of ATM MACHINES, BANK BRANCHES AND PERSONNEL EDUCATION), Interest Rates] and one level of personal Property Bracket (over 200,000 €). The odds ratio (OR) of $0.49(\mathrm{p}=0.016)$ for personal marital status means that married people are half as likely to take a loan as unmarried people. The OR of $1.10(p=0.016)$ shows that for 1 point increase in the customer service score, the possibility of taking a loan increases by 1.10. Improved Shop Design seems to lower the possibility of taking a loan, while satisfaction from the bank's products or the bank itself seems not to play any role. What is important is that Interest Rates play a role $(\mathrm{OR}=1.37, \mathrm{p}=0.012)$, showing that an increase in 1 point of the score of Interest rates (meaning a more positive interest rate policy, i.e. lower and more sensible and 'socially acceptable' interest rates) increased the possibility of taking a loan by 1.37. The above results agree with the findings of Calza et al. (2003).

Table 7. Logistic Regression Results

\begin{tabular}{|l|l|l|}
\hline Variables & Odds Ratio (95\% CI) & P-value \\
\hline Personal Marital Status & & 0.016 \\
\hline Not Married & Ref. & 0.016 \\
\hline Married & $0.49(0.27-0.88)$ & 0.200 \\
\hline Sector of Employment & & \\
\hline Public Sector & Ref. & 0.558 \\
\hline Private Sector & $0.83(0.45-1.54)$ & 0.073 \\
\hline Self-Employed & $0.43(0.17-1.08)$ & 0.157 \\
\hline Personal Property Bracket & & \\
\hline$\leq 10,000 €$ & Ref. & 0.548 \\
\hline $10,001-50,000 €$ & $1.24(0.62-2.47)$ & 0.833 \\
\hline $50,001-100000 €$ & $0.90(0.35-2.32)$ & 0.138 \\
\hline $100,001-200,000 €$ & $2.51(0.75-8.47)$ & 0.033 \\
\hline Over 200,000 $€$ & $3,88(1.12-13.47)$ & 0.484 \\
\hline Products & $0.95(0.83-1.10)$ & \\
\hline Service Quality & & 0.016 \\
\hline Customer service & $1.10(1.02-1.19)$ & 0.038 \\
\hline Shop Design & $0.93(0.87-0.99)$ & 0.592 \\
\hline Satisfaction & $0.98(0.92-1.05)$ & \\
\hline Loans-associated factors & & 0.258 \\
\hline General & $0.94(0.85-1.04)$ & 0.348 \\
\hline Instalments & $1,05(0.95-1.17)$ & 0.570 \\
\hline Insurance/Guarantees & $0.97(0.86-1.09)$ & 0.012 \\
\hline Interest Rates & $1.37(1.07-1.74)$ & 0.997 \\
\hline Constant & 1.006 & \\
\hline
\end{tabular}




\section{Discussion}

The researchers performed a crosssectional study of Greek citizens in order to determine factors affecting their decision to take out a loan from commercial banks. Our scale has been validated with confirmatory factor analysis and logistic regression analysis with dependent variable of taking a loan or not was performed to determine associated factors. Results indicate that the following factors determine the demand for bank loans:

Firstly, lending interest rates. A lower interest rate decreases the cost of a loan, hence increases the demand for bank loans. Important research papers in this respect are the papers of Calza et al. (2003) and Nieto (2007). The financial position of the borrower plays an important role and this is related to the country's GDP. This indicates that in times of a financial crisis as is the case in Greece today, it is natural for loan demand to be low and the probability of a bank accepting the application of a customer for loan to be minimal.

Secondly, service quality factors seem to affect very much the decision to take out a loan. In particular, customer services and shop design of the bank affect a citizen's decision to take out a loan. This result is in agreement with the classical theory of Parasuraman et al. (1988), who point out the importance of service quality in developing customer loyalty through customer satisfaction.

Social factors, such as the marital status of the borrower, play an important role to receive a bank loan. Nevertheless, the bank is an enterprise that must abide by some ethical principles, one of which is relaxation -whenever possible- of the lending interest rate and a more just redistribution of the wealth for the benefit of its customers.

This is, to the best of our knowledge, the first empirical study in Greece, implementing confirmatory factor analysis and logistic regression as the main statistical tools for the determination of the influencing factors of bank loans demand.

\section{Limitations \& Further Recommendations}

Although the present study provides insights into factors affecting Greek customer's decision to take a loan from a bank, there are some limitations that are worth noticing. A major limitation is that the results of this study are based on a small sample (277 Greek customers). Moreover, the participants of our questionnaire were people from the larger area of Athens. This could be a possible factor in creating bias to our results, because people from the capital may have different views on taking a loan compare to those who live far away from the capital. Finally, the researchers did not include all the possible factors that might influence a customer's decision to choose a particular bank.

The case of Greek customers' opinion about loans attracts the interest of both researchers and bankers/managers, who want to identify what the interaction is between people and banks in the period of a financial crisis. A future study investigating the factors that affect Greek customers' decision to take a loan should be conducted. This study continues to investigate the factors affecting customers' decision to take a loan until today. The researchers try to restrict the current limitations by focusing on a large representative sample from customers from all regions of Greece and not only from Athens.

\section{References}

Al-Ajmi, J., Abo Hussain, H. \& Al-Saleh, N. (2009)."Clients of Conventional and Islamic Banks in Bahrain: How They Choose Which Bank to Patronize," International Journal of Social Economics, 36 (11), 1086-1112.

Alexiou, C. \& Sofoklis, V. (2009)."Determinants of Bank Profitability: Evidence from the Greek Banking sector," Economic Annals, 54 (182), 93-118.

Almossawi, M. (2001)."Bank Selection Criteria Employed by College Students in Bahrain: An Empirical analysis," International Journal of Bank Marketing, 19 (3), 115-125. 
Anderson, W. T., Fox, E. P. \& Fulcher, D. G. (1976)."Bank Selection Decision and Market Segmentation," Journal of Marketing, 40 (1), 40-45.

Angur, M. G., Nataraajan, R. \& Jaheera, J. S. (1999)."Service Quality in the Banking Industry: An Assessment in a Developing Economy," International Journal of Bank Marketing, 17 (3), 116-125.

Arasli, H., Turan Katircioglu, S. \& MehtapSmadi, S. (2005)."A Comparison of Service Quality in the Banking Industry: Some Evidence from Turkish and Greek Speaking Areas in Cyprus," International Journal of Bank Marketing, 23 (7), 508-526.

Athanasoglou, P. P., Brissimis, S. N. \& Delis, M. D. (2005)."Bank-Specific. IndustrySpecific and Macroeconomic Determinants of Bank Profitability," Bank of Greece Working Paper 25.

Avkiran, N. K. (1994)."Developing an Instrument to Measure Customer Service Quality in Branch Banking," International Journal of Bank Marketing, 12 (6), 10-18.

Bejou, D., Ennew, C. T. \& Palmer, A. (1998)."Trust, Ethics and Relationship Satisfaction," International Journal of Bank Marketing, 16 (4), 170-175.

Bloemer J., De Ruyter, K. \& Peeters, P. (1998)."Investigating Drivers of Bank Loyalty: the Complex Relationship between Image, Service Quality and Satisfaction," International Journal of Bank Marketing, 16 (7), 276-285.

Boyd, W. L., Leonard, M. \& White, C. (1994)."Customer Preferences for Financial Services: An Analysis," International Journal of Bank Marketing, 12 (1), 9-15.

Brissimis, S. N., Kamberoglou, N. C., \& Simigiannis, G. T. (2001).Is There A Bank Lending Channel Of Monetary Policy In Greece? Evidence from Bank Level Data, European Central Bank Working Paper No. 104.

Calza, A., Gartner, C. \& Sousa, J. (2003)."Modelling the Demand for Loans to the Private Sector in the Euro Area," Applied Economics, 35 (1), 107-117.
Chua, E. K. (1981). 'Customer Intention to Deposit at Banks: an Empirical Investigation of Its Relationship with Attitude, Normative Belief and Confidence,' National University of Singapore, Thesis Collection, Singapore.

Cicic, M., Brkic, N. \& Agic, E. (2004). 'Bank Selection Criteria Employed by Students in a South-Eastern European Country: An Empirical Analysis of Potential Market Segments' Preferences,' International Journal of Bank Marketing, 27 (2), 1-18.

Coyle, T. (1999).'The Bank of Tomorrow,' Americans Community Banker, 8 (7), 16-18.

Denton, L. \& Chan, A. K. K. (1991)."Bank Selection Criteria of Multiple Bank Users in Hong Kong," International Journal of Bank Marketing, 9 (5), 23-34.

Drake, C., Gwynne, A. \& Whaite, N. (1998)."Barclays Life Customer Satisfaction and Loyalty Tracking Survey: A Demonstration of Customer Loyalty Research in Practice," International Journal of Bank Marketing, 16 (7), 287-292.

Erol, C., Kaynak, E. \& El-Bdour Radi (1990)."Conventional and Islamic banks: Patronage Behavior of Jordanian Customers," International Journal of Bank Marketing, 8 (4), 25-35.

Evans, R. H. (1979).'Bank Selection: It All Depends on the Situation, Journal of Bank Research, 12(1), 243-249.

Gerrard, P. \& Cunningham, B. (2001)."Bank Service Quality: A Comparison between a Publicly Quoted Bank and a Government Bank in Singapore," Journal of Financial Services Marketing, 6 (1), 50-66.

Goode, M. \& Moutinho, L. (1995)."The Effects of Free Banking on Overall Satisfaction: the Use of Automated Teller Machines," International Journal of Bank Marketing, 13 (4), 168-190.

Haron, S., Ahmed, N. \& Planisek, S. L. (1994)."Bank Patronage Factors of Muslim and Non-Muslim Customers," International Journal of Bank Marketing, 12 (1), 32-40. 
Holstius, K. \& Kaynak, E. (1995)."Retail Banking in Nordic Countries: The Case of Finland," International Journal of Bank Marketing, 13(8), 10-20.

Javalgi, R. G., Armaco, R. L. \& Hoseini, J. C. (1989)."Using the Analytical Hierarchy Process for Bank Management: Analysis of Consumer Selection Decisions", Journal of Business Research, 19 (1), 33-49.

Kamakodi, N. \& Khan, B. A. (2008)."An Insight into Factors Influencing Bank Selection Decisions of Indian Customers," Asia-Pacific Business Review, 4(1), Available at: http://www.freepatentsonline.com/article/ Asia-Pacific-Business-

Review/179978535.html.

Karatepea, O. M., Yavas, U. \& Babakus, E. (2005)."Measuring Service Quality of Banks: Scale Development and Validation," Journal of Retailing and Consumer Services, 12(1), 373-383.

Kaufman, G. G. (1967). 'A Survey of Business Firms and Households View of a Commercial Bank,' Report to the Federal Reserve Bank of Chicago, Appleton, University of Wisconsin, Madison, WI.

Kaynak, E. \& Kucukemiroglu, 0. (1992)."Bank and Product Selection: Hong Kong," International Journal of Bank Marketing, 10(1), 3-16.

Kaynak, E. \& Yavas, U. (1985)."Segmenting the Banking Market by Account Usage: an Empirical Investigation," Journal of Professional Service Marketing, 1 (1), 177188.

Kazeh, K. \& Decker, W. H. (1993).'How Customers Choose Banks,' Journal of Retail Banking, 14 (4), 92-93.

Kennington, C., Hill, J. \& Rakowska, A. (1996)."Consumer Selection Criteria for Banks in Poland," International Journal of Bank Marketing, 14 (4), 12-21.

Laroche, M., Rosenblatt, J. A. \& Manaing, T. (1986)."Services Used and Factors Considered Important in Selecting a Bank: an Investigation across Diverse Demographic Segments," International Journal of Bank Marketing, 4 (1), 35-55.
Lee, J. \& Marlowe, J. (2003)."How Consumers Choose a Financial Institution: Decision-Making Criteria and Heuristics," International Journal of Bank Marketing, 21 (2), 53-71.

Lenka, U., Suar, D. \& Mohapatra, P. K. J. (2009)."Service Quality,Commercial Banks, Customer Satisfaction, and Customer Loyalty in Indian," Journal of Entrepreneurship, 18 (1), 47-64.

Maddern, H., Maull, R. \& Smart, A. (2007).'Managing Service Quality in Banks: Customers' Gender Effects,' International Journal of Operational and Production Management, 27 (9), 998-1019.

Mason, J. B. \& Mayer, M. L. (1974).'Differences between High-and-LowIncome Savings and Checking Account Customers,' The Magazine of Bank Administration, 65 (1), 48-52.

Mokhlis, S. (2009).'Determinants of Choice Criteria in Malaysia's Retail Banking: An Analysis of Gender-Based Choice Decisions,' European Journal of Economics, Finance and Administrative Sciences, 1 (2), 1450-1467.

Mylonakis, J., Malliaris, P. J. \& Siomkos, G. J. (1998)."Marketing-Driven Factors Influencing Savers in the Hellenic Bank Market," Journal of Applied Business Research, 14 (2), 109-116.

Newman, K. ～(2001)."Interrogating SERVQUAL: A Critical Assessment of Service Quality Measurement in a High Street Retail Bank," International Journal of Bank Marketing, 19 (3), 126-39.

Newman, K. \& Cowling, A. (1996)."Service Quality in Retail Banking: the Experience of Two British Clearing Banks," International Journal of Bank Marketing, 14 (6), 3-11.

Nieto, F. (2007)."The Determinants of Household Credit in Spain," Available at: http://papers.ssrn.com/sol3/papers.cfm?ab stract_id=996381. Accessed: 23-Jul-11.

Nunnally, J. C. (1978). Psychometric Theory, McGraw-Hill, New York.

Oldfield, B. M. \& Baron, S. (2000)."Student Perceptions of Service Quality in a UK University Business and Management 
Faculty," Quality Assurance in Education, 8 (2), 85-95.

Parasuraman, A., Berry, L. L. \& Zeithaml, V. A. (1991a).'Refinement and Reassessment of the SERVQUAL Scale,' Journal of Retailing, 67 (4), 420-450.

Parasuraman, A., Berry, L. L. \& Zeithaml, V. A. (1991b)."Understanding Customer Expectations of Service," Sloan Management Review, 32 (3), 39-48.

Parasuraman, A., Zeithaml, V. A., \& Berry, L. L. (1988)."SERVQUAL: a Multiple-Item Scale for Measuring Consumer Perceptions of Service Quality," Journal of Retailing, 64 (1), 12-40.

Rao, S. \& Sharma, R. K. (2010)."Bank Selection Criteria Employed by MBA Students in Delhi: An Empirical Analysis," Journal of Business Studies, 1 (2), 56-69.

Riggall, J. (1980). 'A New Study: How Newcomers Select Banks,' American Bankers Association Banking Journal, 72 (7), 93-94.

Salime, M. S. (2010)."In search of Value for their Money : Banking Preferences and Service Quality Perceptions of local and Expatriate Retail Bank Customers," International Journal of Economic Perspectives, 4 (2), 1-14.

Segars, A. H. (1997)."Assessing the Unidimensionality of Measurement: A paradigm and Illustration within the Context of Information Systems Research," Omega, 25 (1), 107-121.

Sekaran, U. (1992). Research Methods for Business:A Skill-Building Approach, Wiley, New York.

Senyucel, E. (2009)."Evaluation of SERVQUAL Instrument as Bank Selection Criteria in the Banking Industry: Empirical Evidence from Turkish and Greek Speaking Areas in Cyprus," Banking and Finance Letters, 1 (1), 21-28.

Sinkula, J. M. \& Lawtor, L. (1988).'Bank Characteristics and Customer Bank Choice: How Important are Importance Measures,' Journal of Professional Services Marketing, 3 (3), 131-41.
Sureshchandar, G. S., Rajendran, C. \& Anantharaman, R. N. (2003)."Customer Perceptions of Service Quality in the Banking Sector of a Developing Economy: a Critical Analysis," International Journal of Bank Marketing, 21 (5), 233-242.

Ta, H. P. \& Har, K. Y. (2000)."A Study of Bank Selection Decisions in Singapore Using the Analytical Hierarchy Process," International Journal of Bank Marketing, 18(4), 170-180.

Thwaites, D. \& Vere, L. (1995)."Bank Selection Criteria - a Student Perspective," Journal of Marketing Management, 11 (1-3), 133-149.

Yavas, U., Bilgin, Z. \& Shemwell, D. J. (1997)."Service Quality in the Banking Sector in an Emerging Economy: A Consumer Survey," International Journal of Bank Marketing, 15 (6), 217-223.

Ying, L. C. \& Chua, A. (1989). 'Customer Bank Selection: Bank Marketing Implication,' Malaysian Management Review, 24 (3), 55-67.

Yue, H. \& Tom, G. (1995). 'How the Chinese Select their Banks,' Journal of Retail Banking, 16(4), 36-39.

Zhou, L. (2004)."A Dimension-Specific Analysis of Performance Only Measurement of Service Quality and Satisfaction in China's Retail Banking," Journal of Services Marketing 18 (7), 534-546.

Zineldin, M. (1996)."Bank Strategic Positioning and Some Determinants of Bank Selection," International Journal of Bank Marketing, 14 (6), 12-22. 